\title{
The Influence Experiential Marketing and Customer Value to Loyalty Moslem Tourists
}

\author{
Nurdin Sobari' ${ }^{1}$, Hardius Usman ${ }^{2}$, Puja Prasetia ${ }^{3}$ \\ \{ ${ }^{1}$ nurdin.sobari@ui.ac.id, ${ }^{2}$ hardius@ stis.ac.id, ${ }^{3}$ puja.nutrifood@gmail.com $\}$ \\ ${ }^{1,2,3}$ School of Strategic and Global Studies, Universitas Indonesia, Indonesia
}

\begin{abstract}
This research aims to examine the effects of experiential marketing and customer value on satisfaction and loyalty in halal tourism in Indonesia. A total of 175 questionnaires were distributed using the criteria of Indonesian tourists who ever enjoyed halal tourism by visiting Indonesian tourist attractions. The analysis methods employed were the factor analysis and the Structural Equation Model (SEM) with explorative approaches. Findings of this research reveal that experiential marketing has a positive and significant effect on satisfaction and loyalty, the indicator sense has the most dominant value and is able to leave the impression that creates satisfaction and causes loyalty among Muslim tourists. Customer value has a positive and significant effect on satisfaction but it does not affect loyalty. This proves that satisfaction does not always serve as the determinant of loyalty.
\end{abstract}

Keywords: experiential marketing, customer value, satisfaction, loyalty, halal tourism

\section{INTRODUCTION}

In this global era, tourism is one of the driving forces of the world economy and it contributes $9 \%$ to the global GDP (UNWTO, 2014). From the magnitude of existing potential, business actors and the government are required to determine new strategies to attract tourists to visit. One of the strategies to realize this goal is to create new market segments. Halal tourism is one of the new market segments which attract considerable attention.

Halal tourism is a type of tourism destined for Muslim tourists. The enormous population of Muslims offers one of the great opportunities to make a profit. If 1 out of 3 people born between 1990 and 2030 are Muslims, the Muslim population might increase to 2.2 billion by 2030 (Pew Research Center, 2014).

In 2014, there were 116 million Muslim tourists who travelled for pleasure around the world and this number is predicted to increase to 180 million Muslim tourists in 2020 (Comcec, 2016). In the halal tourism market, Muslim tourists spent US \$151 billion in 2015 and this will continue to increase. It is predicted that in 2021, Muslim tourists will spend US \$243 billion on halal tourism or $8.2 \%$ of the total world expenditure. (Reuters \& Standard, 2016).

Currently, a marketing strategy to attract tourists is in demand because the current marketing is still using traditional marketing strategies. Traditional marketing views tourists as rational, decision-making of functional features, and benefits. In the current global era, there is a need 
for the added value which tourists need. Tourists are not only a matter of rationality, but also the emotional aspect which focuses on a fun travel experience (Schmitt, 1999).

Experiential marketing is a marketing strategy that evolves from traditional marketing. A shift from the marketing of traditional features and benefits to the creation of experiences for tourists. In addition to experiential marketing, there is another important thing to consider, namely customer value. Customer value is one of the factors why one makes a purchase decision based on the information he gets. Thus, the better the value of a product or service is, the greater the enthusiasm of tourists to understand, pay attention to, and elaborate the information about the purchase of the said product or service is.

If expressed in a mathematical formulation, customer value is defined as the total benefit or quality divides by the price. Furthermore, this formulation may changes depending on two aspects, namely price and quality. Considering the development of the derivatives of these components, it is not surprising that it requires a high level of creativity from tourism business actors to be able to manage customer value. The victory of a brand is often determined by how well they can deliver "superior customer value" to tourists (Zoel, 2011). The question which serves as the basis is that: What are the choices offered in the competition? Do you want to compete in the cheap price? Do you want to compete in the quality as a way to differentiate? Or, is it possible to provide "super value", i.e. cheap in price but excellent in quality?

The essence of experiential marketing and customer value has something to do with the loyalty of Muslim tourists. If relying on promotions as a way to attract tourists, then they require a high cost. Tourists' revisit or loyalty does not cost a lot of money to maintain tourists, rather than attracting new tourists as the main component to keep Indonesian tourism alive in the long run is the loyalty of Muslim tourists (Aydin and Ozer, 2005). When tourists enjoy the product or service and have a memorable experience while consuming it, they will become loyal tourists, even they will be willing to spread information about the product to anyone around them, this is known as the word of mouth (Alma, 2011).

Based on the description of the problems to be studied, the purpose of this research is to analyze the effects of experiential marketing and customer value on the loyalty of Muslim tourists and the effects of satisfaction on the loyalty of Muslim tourists.

\section{LITERATURE REVIEW}

Recently, we become familiar with the terms Muslim tourism, religious tourism, shariabased tourism, and halal tourism. These four terms have fundamental differences in terms of their activities and objectives:

1) Islamic tourism, as the name implies, is a type of tourism in which all the tourists are Muslim and travel activities aim to contemplate the miracles of Allah's creation and enjoy the beauty of this universe, which in turn will make the human soul develop a strong faith in the oneness of Allah and help one to fulfill his life obligation (Jaelani, 2017).

2) Religious tourism can be defined as a type of tourism that is motivated, either partially or entirely, by religious reasons (Rinschede, 1992). According to the Presidential Decree No. RI. 50 of 2011 concerning the Master Plan of National Tourism Development Article 14 paragraph 1, religious tourism is a type of tourism where the destination object is something religious such as a place of worship, the tomb of the Sunan, or learning the history of a particular religion by visiting the historic sites of Islam. Besides, it is not only intended for 
Muslim tourists, but also for non-Muslims where they can have religious tours by visiting sacred places according to their respective religion such as churches, temples, and inscriptions.

3) Sharia-based tourism refers to activities supported by various facilities and services provided by the community, businessmen, the government, and local governments that comply with Sharia (Kemenpar, 2012). Sofyan (2012) asserts that sharia-based tourism has a broader definition than that of religious tourism, i.e. it refers to a type of tourism which is based on the values of Islamic sharia.

4) Halal tourism refers to a type of tourism in which all tourism objects are free from things which cause harmful or detrimental effects, both physically and mentally. The making of things such as foods, beverages, medicines, and other materials are guaranteed to be halal. In addition to the culinary aspect, halal tourism includes all the objects and hotels whose operations comply with halal certification. The term halal tourism word puts a greater emphasis on the management which should be both halal and thoyyib. Halal tourism is a new tourism concept. It is not the same as religious tourism such as umrah and hajj. Halal tourism is a type of tourism that caters for holidays, by adjusting the holiday style according to the needs and demands of Muslim tourists. In this case, hotels implementing sharia principles do not serve alcoholic beverages and have separate swimming pools and spa facilities for men and women (Wuryasti, 2013)

The concept of halal tourism is a process of integrating Islamic values into all aspects of tourism activities (Tourism Review, 2013). The values of Islamic sharia as a belief embraced by Muslims serve as a fundamental basis in creating tourism activities.

The existing concept of halal tourism must consider the aspect of tourists' satisfaction in establishing loyalty. One of the factors is experiential marketing. Experiential marketing comes from a set of interactions between customers and a product, a company, or a part of an organization, which provoke reactions. This experience is personal and implies customer engagement at a different level (rational, emotional, sensory, physical, and spiritual) (Gentile, Spiller, and Noci, 2007). Besides, customer responses both subjectively and internally as a result of interacting directly and indirectly with stakeholders or companies (Meyer and Schwager, 2007). Customer Experience, namely physical and emotional, (Colin Shaw and John Ivens, 2007) is not influenced by a single element/aspect only, but it is influenced by a combination of various aspects such as product, service, brand, channel, and promotion. Maghnati et al. (2012) state that experiential marketing does not neglect the quality and function of a particular product and service, but it enhances customers' emotion and provides stimuli to their mind. The main point of experiential marketing is to connect with customers using some approach levels. These approach levels can be classified into 5 experiential marketing dimensions proposed as a form of application of approaches which a company can use to provide experiences to its customers. The five dimensions are Sense, Feel, Think, Act, and Relate (Schmitt, 1999).

In addition, there is another factor that may affect tourists' satisfaction in forming loyalty, namely customer value. Customer value refers to the differential between the evaluation undertaken by prospective customers of all the benefits and costs of a particular offer and other alternatives which they think (Kotler, 2005). Customer value deals with benefits and sacrifices, in which customers will compare the benefits gained with the sacrifices made because the value is determined by customers in the context of something unique (Scott Robinette and Claire 
Brand, 2001). Customer value is broken down into 5 value factors called Value Star, they are price, product, equity, experience, and energy. Value Star divides value into two, namely emotional value and rational value. The following description will explain the five factors of value star (Scott Robinette and Claire Brand, 2001).

Loyalty refers to customers' willingness to always use a company' s products over a long period of time, even they use them exclusively, recommend those products to others (Lovelock et al., 2010). Customer loyalty emerges because customers have been determined to remain making repeat purchases on certain products sometime later in the future despite possible changes in marketing efforts and situations that will result in a change in customers' behavioral transition. (Kotler and Keller, 2008).

There are two factors which determine loyalty to particular tourism destinations. The first one is "the intention to revisit the destination", which means that tourists express their loyalty by revisiting particular tourism destinations in the future. The second one is "saying positive things about the destination and recommendations to others", this means that tourists express their loyalty by saying something positive about a particular tourism destination and recommend it to others (Artuğer et al., 2013).

The framework developed based on the above theoretical review is presented below:

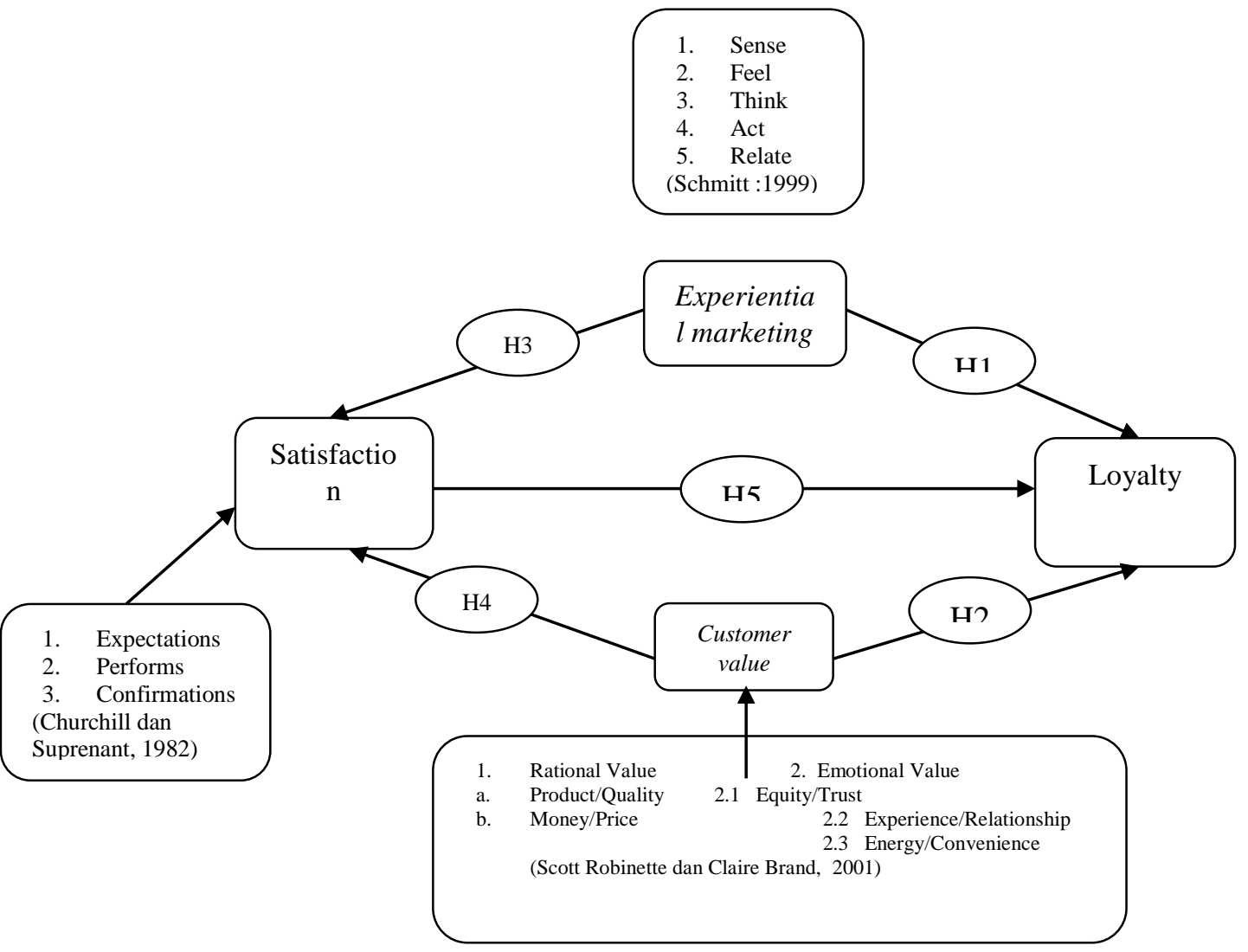

1. Intention to revisit the destination

2. Say positive things about the destination and recommendations to others

(Artuğer et al., 2013).

Figure 1 Research Framework 


\section{HYPOTHESES}

Based on the above conceptual framework, this research develops the following hypotheses: Hypothesis 1: Experiential marketing has a positive and significant effect on the loyalty of Muslim tourists.

Experiential marketing is one of the concepts to run a marketing strategy. This concept explores deeper into what tourists feel overall as they visit a particular place. Furthermore, it can encourage tourist loyalty. Chen et al. (2008) find out that the elements of experiential marketing, which consist of sense, feel, think, act, and relate, and the loyalty of online customers or virtual customers are positively correlated.

Hypothesis 2: Customer value has a positive and significant effect on the loyalty of Muslim tourists.

Customer value is an approach to tourists by viewing them from two perspectives, namely logic and emotions. To realize its objectives, a company must realize these two points because once tourists have felt the benefits from halal tourism, this will result in their loyalty. According to Kotler and Armstrong (2011), once a company creates value for customers, a strong relationship with its customers can be built.

Hypothesis 3: Experiential marketing has a positive and significant effect on the satisfaction of Muslim tourists.

According to the experiential marketing concept, a company will target the rational and emotional aspects of tourists, because both aspects have a tremendous effect in marketing on tourist satisfaction. Findings of the research by Chou You-Ming (2010) discuss the effect of experiential marketing on customer satisfaction based on relationship quality and it was revealed that experiential marketing has a positive relationship with tourists' satisfaction.

Hypothesis 4: Customer value has a positive and significant effect on the satisfaction of Muslim tourists.

Customer value is a variable that plays a role in encouraging tourists' satisfaction, the concept of value creation requires undivided attention to attract and maintain tourists such as by maximizing quality or reducing costs to get such satisfaction. Findings of the research by Mardikawati (2013) suggest that customer value has a positive and significant effect on customer satisfaction.

Hypothesis 5: Satisfaction of Muslim tourists has a positive and significant effect on the loyalty of Muslim tourists.

In general, satisfaction refers to the feeling which customers feel after evaluating one or more experiences they have after using a particular service product (Sumardi \& Soliha, 2015). When the satisfaction which customers feel reaches the optimal level, this will result in customer loyalty.

\section{RESEARCH METHODOLOGY}

This research adopted several theories, namely, experiential marketing from Bernd Schmitt (1999), Customer Value from Scott Robinette and Claire Brand (2001), Tourist Satisfaction from Churchill and Suprenant (1982), and Tourist Loyalty from Artuğer (2013). This research was a quantitative research with the primary data distributed online to 175 respondents of Muslim tourists using Google Docs application and the secondary data through literature. This 
research method was a factor analysis with Structural Equation Model (SEM) using AMOS 24 software.

The data were analyzed using Structural Equation Model (SEM), i.e., a statistical technique that allows testing of a relatively complex series of relations simultaneously (Wijanto, 2007). Bollen and Long in Wijanto (2007: 34) state that SEM procedure generally contains stages of model specification, identification, estimation, matching test, and interpretation and respesification.

\section{RESEARCH RESULTS}

\subsection{Validity and Reliability Tests of the Questionnaire}

Assessment of the validity of the questionnaire can be done by looking at the KMO, MSA, and Barlett's test values. If the values are above 0.5 and Barlett's test with $5 \%$ significance, the questionnaire is valid. The questionnaire can be said to be valid if Cronbach's Alpha value is more than 0.6 to close to 1 .

Table 1. Validity and Reliability Tests of the Questionnaire

\begin{tabular}{|c|c|c|c|}
\hline No & Jenis Kelamin & Jumlah & Prosentase \\
\hline 1 & Laki-Laki & 70 & $40 \%$ \\
\hline \multirow[t]{2}{*}{2} & Perempuan & 105 & $60 \%$ \\
\hline & Jumlah & 175 & $100 \%$ \\
\hline No & Usia & Jumlah & Prosentase \\
\hline 1 & $>40$ tahun & 9 & $5 \%$ \\
\hline 2 & $\leq 20$ tahun & 6 & $3 \%$ \\
\hline \multirow[t]{3}{*}{3} & $21-30$ tahun & 137 & $78 \%$ \\
\hline & $31-40$ tahun & 23 & $13 \%$ \\
\hline & Jumlah & 175 & $100 \%$ \\
\hline No & Pendapatan & Jumlah & Prosentase \\
\hline 1 & < Rp. 1.000 .000 & 22 & $13 \%$ \\
\hline 2 & > Rp. 5.000.001 & 60 & $34 \%$ \\
\hline 3 & Rp 1.000.001 - Rp. 2.000 .000 & 10 & $6 \%$ \\
\hline 4 & Rp. 2.000.001-Rp. 3.000 .000 & 11 & $6 \%$ \\
\hline 5 & Rp. 3.000.001-Rp. 4.000 .000 & 43 & $25 \%$ \\
\hline \multirow[t]{2}{*}{6} & Rp. $4.000 .001-$ Rp. 5.000 .000 & 29 & $17 \%$ \\
\hline & Jumlah & 175 & $100 \%$ \\
\hline No & Pendidikan & Jumlah & \\
\hline 1 & D3 & 19 & $11 \%$ \\
\hline 2 & S1 & 120 & $69 \%$ \\
\hline 3 & $\mathrm{~S} 2$ & 11 & $6 \%$ \\
\hline \multirow[t]{2}{*}{4} & SMA & 25 & $14 \%$ \\
\hline & Jumlah & 175 & $100 \%$ \\
\hline No & Pengeluaran & Jumlah & \\
\hline 1 & $<$ Rp. 1.000 .000 & 28 & $16 \%$ \\
\hline 2 & $>$ Rp. 5.000 .001 & 22 & $13 \%$ \\
\hline 3 & Rp 1.000.001 - Rp. 2.000 .000 & 34 & $19 \%$ \\
\hline 4 & Rp. 2.000.001-Rp. 3.000 .000 & 48 & $27 \%$ \\
\hline
\end{tabular}




\begin{tabular}{|r|l|r|r|}
5 & Rp. 3.000.001-Rp. 4.000.000 & 28 & $16 \%$ \\
\hline 6 & Rp. 4.000.001 - Rp. 5.000.000 & 15 & $9 \%$ \\
\hline & Jumlah & 175 & $100 \%$ \\
\hline No & Pekerjaan & Jumlah & Prosentase \\
\hline 1 & Guru & 7 & $4 \%$ \\
\hline 2 & Ibu rumah tangga & 9 & $5 \%$ \\
\hline 3 & Karyawan BUMN & 5 & $3 \%$ \\
\hline 4 & Karyawan swasta & 415 & $66 \%$ \\
\hline 5 & Pegawai negeri sipil & 31 & $2 \%$ \\
\hline 6 & Pelajar/Mahasiswa & 4 & $18 \%$ \\
\hline 7 & Wiraswasta & 175 & $2 \%$ \\
\hline & Jumlah & $100 \%$ \\
\hline
\end{tabular}

The above table shows that all the questionnaires are considered valid because the KMO is above 0.5 and all the variables above are reliable because the Cronbach's Alpha values are above 0.6. This stage deals with the matching test between the model and the data. The following is a summary of the GOF testing results from the initial modification model.

\begin{tabular}{|l|l|l|l|l|}
\hline Variabel & KMO & Barlett's test & Sig & Alpha cronbach \\
\hline Experiential & 0.865 & 903.029 & 0 & 0.949 \\
\hline Customer value & 0.896 & 893.46 & 0 & 0.952 \\
\hline Satisfaction & 0.909 & 1714.539 & 0 & 0.946 \\
\hline Loyalty & 0.5 & 184.039 & 0 & 0.895 \\
\hline
\end{tabular}

Table 2. GOF Testing Results Initial Model after Modification Source: Results of Data Processing

\subsection{Testing Hypothesis Results}

Based on the testing results of goodness of fit as contained in the table above, the model of initial modification result can be said fit based on data that have been processed.

Table 3. Summary Results of Hypotheses Test

\begin{tabular}{|lll|l|l|l|l|}
\hline & & & Estimate & S.E. & C.R. & P \\
\hline \multirow{2}{*}{$\begin{array}{l}\text { SAT } \\
\text { SAT }\end{array}$} & $<---$ & EM & 0.414 & 0.158 & 2.622 & 0.009 \\
\cline { 4 - 7 } LOY & $<---$ & CV & 0.523 & 0.193 & 2.706 & 0.007 \\
\cline { 3 - 7 } LOY & $<---$ & EM & 0.316 & 0.139 & 2.282 & 0.023 \\
\cline { 4 - 7 } LOY & $<---$ & SV & 0.055 & 0.167 & 0.33 & 0.741 \\
\cline { 4 - 7 } & & SAT & 0.582 & 0.109 & 5.339 & $* * *$ \\
\hline
\end{tabular}

Source: Results of Data Processing

The table above shows that every number of C.R. is same with t-count, so that a comparison will be made between t-count and critical point with a significance level of $5 \%$. The critical 
point value at $5 \%$ significance is 1.96 . If the value of C.R. is greater than its critical value with a significance level of $\mathrm{p}<0.05$, the proposed hypothesis is accepted or vice versa, if the value of C.R. has not been able to reach its critical value at the significance level $p>0.05$, the proposed hypothesis is rejected.

$\mathrm{H} 1=$ The effect of experiential marketing on Muslim tourist loyalty

The regression coefficient for experiential marketing on Muslim tourist loyalty was positive and statistically significant at the $5 \%$ significance level, with $\mathrm{p}$-value $=0.023$ and $\mathrm{t}$-count $=$ 2.282, so that $\mathrm{H} 0$ was rejected and $\mathrm{H} 1$ was accepted, then hypothesis 1 of the research was supported by data.

This research was in accordance with the research conducted by Risalatin (2015) that there is an effect of experiential marketing on tourist loyalty. So, when the tourists have a very memorable experience and they remember in their minds even touch the sense, feel, think, act, and relate, it encourages the tourists to be loyal, so that they will re-visit and give positive testimony on the trip they have done. The research conducted by Jatmiko (2012) states the need for special attention on the indicators of sense and feel since those are the dominant factors in creating loyalty.

From the results of dominant scores, the indicator of sense has the highest score of the five existing indicators. This means that business actors already understand about the mindset of Muslim tourists and they involve many senses of tourists. The smallest dominant score is in the indicator of relate, in which from the results of data processing still tends to agree. The concept of relate is like when we choose something, it signifies that we are in such social status. It means that halal tourism in Indonesia has been able to make Muslim tourists in their social status, and there is an attachment and pride as a Muslim to keep running entertainment by sticking to the teachings of Islam.

Loyal tourists are the assets of Indonesia's halal tourism industry, because the loyal customers must be through the satisfaction stage, and when the tourists are satisfied, they become a means of advertising and promotion for this halal tourism. In addition, the loyal attitude of the tourists is the most inexpensive promotion to retain tourists rather than looking for the new one.

$\mathrm{H} 2=$ The effect of customer value on Muslim tourist loyalty

The regression coefficient for customer value on Muslim tourist loyalty was positive and not statistically significant at $5 \%$ significance level, with $\mathrm{p}$-value $=0.741$ and $\mathrm{t}$-count $=0.33$, so that H0 was accepted and H1 was rejected. The hypothesis 2 of the research was not supported by data.

This was contrary to the previous studies. The research conducted by Atalik and Arslan (2009) shows that there is a significant effect between customer value and loyalty. In addition, the research conducted by Yenny and Hartono (2014) also shows that there is a significant effect between customer value and loyalty. Their research also states the need to increase customer value in terms of providing better services to make more loyal customers.

Looking back at the definition of customer value according to Kotler (2005), that customer value is the difference between the evaluation of potential customers for all benefits and all the costs of an offer. The definition emphasizes on the costs associated to price, so it allows tourists not to be loyal, since price is a flexible indicator. If tourists are loyal to the price, then when the price changes, tourist loyalty also changes or even decreases. 
As expressed by Scott Robinnete and Claire Brand (2001), if tourists only travel by price, the tourists are only loyal to the price whereas price is a flexible indicator.

If every business actor used to assume that every satisfied consumer is enough and will lead to a loyal attitude, it does not apply any more. Reichheld (1994) states that the customers who describe themselves satisfied are not necessarily loyal and there could be other better tours which can make them satisfied and loyal. According to this research, customer value has a significant and positive effect on satisfaction but not for loyalty. This shows that there are better options besides halal tours.

H3 = The effect of experiential marketing on Muslim tourist satisfaction

The regression coefficient for the experiential marketing variable on Muslim tourist satisfaction was positive and statistically significant at the $5 \%$ significance level, with p-value $=0.009$ and $\mathrm{t}$-count $=2.622$, so that $\mathrm{H} 0$ was reject and $\mathrm{H} 1$ was accepted. The hypothesis 3 of the research was supported by data.

This was in accordance with the research conducted by Risalatin (2015) that there is a positive and significant relationship between experiential marketing and satisfaction of tourists. Risalatin (2015) states that customer experience is an important variable and needs to be considered, so that tourists have a deep impression to create satisfaction during traveling.

According to Schmitt (1999), the more senses are felt, the more impressed and satisfied the tourists. This is the greatest power to influence tourists in terms of decision. A memorable experience after making a purchase is a key to the satisfaction of tourists. It is different from traditional marketing that only focuses on sales without thinking of tourists after decision making and traveling.

Of the five existing indicators, relate has the lowest score, but still tends to agree. It needs to be a concern for the halal tourism actors; the need for a deeper exploration of how this indicator of relate can be a force to lead to Muslim tourist satisfaction even higher. Branding is needed for the emergence of relate. So, when Muslim tourists do the halal tours, what they feel? Who will they be? How are they looked by others? Such positive perceptions can bring a sense of satisfaction when tourists do halal tours, and the key is in branding.

$\mathrm{H} 4=$ The effect of customer value on Muslim tourist satisfaction

The regression coefficient for the customer value variable on Muslim tourist satisfaction was positive and statistically significant at $5 \%$ significance level, with $\mathrm{p}$-value $=0.007$ and $\mathrm{t}$ count $=2.706$, so that $\mathrm{H} 0$ was rejected and $\mathrm{H} 1$ was accepted. The hypothesis 4 of the research was supported by data.

In addition, this research was generally in accordance with the research conducted by previous researchers, namely, Yang and Peterson (2004). In their research, the same conclusion is drawn that customer value is one of the predictors for satisfaction variable. This is also in accordance with the research conducted by Yenny and Hartono (2014) about the positive and significant effect between customer value and satisfaction and the need for improvement in quality in terms of service, product quality, responding to complaints, and delivering information to increase the sense of satisfaction.

Customer value is an advantage in the forms of monetary value, economic value, service, and social needs obtained by tourists by expending something (Anderson, 1998). If the benefits obtained are less than what are expended, disappointment will appear from tourists, but otherwise, if the benefits obtained are more than what are expected, it will create satisfaction. It is felt by Muslim tourists in doing Halal tours, because in general, tourists want to maximize a 
value of products or services they have chosen (Kottler and Keller, 2007). In addition, Muslim tourist satisfaction is created because a product or service is perceived to have superior value (Khalifa, 2004).

If we look at the score, the dominant indicator was energy. Energy deals with consumer sacrifice related to power and energy spent in time measurements to obtain services. This time measurements may involve travel time, waiting time, and time of enjoying the service. The provider company must consider the aspects of energy and time of the service to provide convenience for customers in using the products and services of the company.

H5 = The effect of Muslim tourist satisfaction on Muslim tourist loyalty

The regression coefficient for the satisfaction variable on Muslim tourist loyalty was positive and statistically significant at the $5 \%$ significance level, with $\mathrm{p}$-value $=0.000$ and $\mathrm{t}$ count $=5.339$, so that $\mathrm{H} 0$ was rejected and $\mathrm{H} 1$ was accepted. The hypothesis 1 of the research was supported by data.

This was in accordance with the previous research conducted by Singh (2006), showing a positive relationship between satisfaction and loyalty which means the satisfaction of tourists will lead tourists to become loyal tourists. The result of this research was also supported by the result of the research conducted by Risalatin (2015) that satisfaction has a direct effect on loyalty. The satisfaction of tourists is very important to note because when the tourists are satisfied, it will create loyalty which the tourists can re-visit or give tourist information to their closest people and positive testimony during traveling.

The satisfaction of Muslim tourist that has been formed through halal tours then created the loyalty of Muslim tourists. In this research, this was created through several factors, namely, the willingness of Muslim tourists to re-visit and give recommendations to family, friends, or closest people. This showed that Muslim tourists have received a value more than expected previously and through some indications of satisfaction, such as the ease to get information, the ease of searching places of worship and public facilities, the sufficient number of sharia hotels, and so on, which make the tourists traveling satisfied because of many conveniences obtained when doing halal tours.

\section{CONCLUSIONS}

The results of the research showed that experiential marketing had a significant and positive effect on satisfaction and loyalty, while customer value had a positive and significant effect on satisfaction but not for loyalty. Satisfaction had a positive and significant effect on loyalty. This proved that satisfaction is not always a determinant of loyalty.

The conclusions in this research cannot be generalized as general conclusions due to limitations in the distribution of samples. This research was only conducted on local tourist respondents. Further studies can be done by taking foreign tourist respondents and further studies need to include other variables that allegedly affect tourist loyalty.

The loyalty of Muslim tourists is obtained through the satisfaction of tourists and the experiential marketing of Muslim. Hence, the managers or related parties need to make an overall improvement in terms of information about halal tourism, management of tourist attraction, availability of sharia hotels, halal certified restaurants, and the ease in finding public facilities like places of worship as well as making an application of halal tourism. In addition, in terms of experiential marketing, it needs a strategy to create a positive experience of Muslim 
tourists and make a halal tour as a new lifestyle and a need. Since the smallest score was in the indicator of relate, this became an opportunity to explore more deeply. However, a strong branding is needed. It was reasonable that the indicator of relate had the lowest score because halal tourism is a new market segment. When the branding of halal tourism is already strong, halal tourism will be a solid, new lifestyle, since a strong religion supports it as well.

For customer value, energy becomes the most dominant average score, so that it becomes an improvement for manager to consider in terms of energy, i.e., time in the service of tourists to maintain the satisfaction of Muslim tourists and the centralization of the halal tourist attractions adjacent to each other. In addition, as Muslim tourists are satisfied with halal tourism, it is necessary to maintain it with customer retention strategy. Customer retention is a strategy in which a customer is loyal to us, so as not to lose or make the customer turn to other products.

\section{ACKNOWLEDGEMENT}

This research based on grant scheme of PITTA (Publikasi International Terindeks untuk Tugas Akhir) or also known as Indexed International Publications for Final Projects toward Universitas Indonesia students. Thank you to The Directorate of Research and Community Engagement of Universitas Indonesia (DRPM UI).

\section{REFERENCES}

[1]. Alma, Buchari. (2011). Manajemen Pemasaran dan Pemasaran Jasa. Bandung : Penerbit Alfabeta.

[2]. Anderson, J. (1998). Bussines Marketing Understand What Customer Value. Harvard Bussiners Review. P-6.

[3]. Artuğer, S., et al. (2013). The effect of destination image on destination loyalty: application in Alanya. European Journal of Business and Management, 5 (13) : 124-136.

[4]. Aydin, S., \& Ozer, G. (2005). The analysis of antecedents of customer loyalty in the Turkish mobile telecommunication Market. Eur. J. Mark., 39(7/8): 910-925.

[5]. Chen, J., Ching, R.K.H. \& Luo, M.M. (2008). Virtual Experiential Marketing on Online Customer Intentions and Loyalty. Proceedings of the 41st Hawaii International Conference on System Sciences

[6]. Churchill, Gilbert A. Jr. and Carol Surprenant. (1982). An Investigation into the Determinants of Customer Satisfaction. Journal of Marketing Research, 19 (November) $491-504$.

[7]. Committe for Economic and Commercial Cooperation of the Organization of Islamic Cooperation. (2016). Moslem Friendly Tourism: Understanding the Demand and Supply Sides In the OIC Member Countries. Ankara : Turkey.

[8]. Dwi Jatmiko, Rohmat \& Andharini, Sri Nastiti. (2012). Analisis Experiential marketing Dan Loyalitas Pelanggan Jasa Wisata. Jurnal Manajemen Dan Kewirausahaan, Vol.14, No. 2, September 2012: 128-137

[9]. Gentile, Chiara, Nicola Spiller and Giulano Noci (2007). How to Sustain the Customer Experience: An Overview of Experience Components that Co-create Value with the Customer. European Management Journal,25 (5),395-410. 
[10]. Hijjah, Risalatin \& Ardiansari, Anindya. (2015). Pengaruh Customer Experience Dan Customer value Terhadap Customer Loyalty Melalui Customer Satisfaction. Management Analysis Journal 4 (4)

[11]. Jaelani, Aan. (2017). Halal tourism industry in Indonesia: Potential and prospects. Munich Personal RePEc Archive

[12]. Kemenpar. (2012, August 4). Kemenparekraf Promosikan Indonesia Sebagai Destinasi Pariwisata halal Dunia. Retrieved from http://www.kemenpar.go.id: http://www.kemenpar.go.id/asp/detil.asp?c=16\&id=2042

[13]. Kotler, P \& Keller.(2008). Manajemen Pemasaran Edisi Kedua belas Jilid 1 \& 2. Jakarta : PT Macanan Jaya Cemerlang.

[14]. Kotler, P., Keller, K.L. (2005). Marketing Management 12th Edition. Pearson International.

[15]. Logiawan, Yenny, Hartono Subagio (2014). Analisis Costumer Value terhadap Costumer Loyalty dengan Costumer Satisfaction sebagai Variabel Intervening pada Restoran Bandar Djakarta Surabaya. Jurnal Manajemen Pemasaran Petra. Vol.2 No.1. Hal.1-11

[16]. Maghnati et. al.. (2012). Exploring the Relationship between Experiential Marketing and Experiential Value in the Smartphone Industry. International Business Research, 5(11).

[17]. Woro, Mardikawati \& Naili, Farida. (2013). Pengaruh nilai pelanggan dan kualitas layanan terhadap loyalitas pelanggan, melalui kepuasan pelanggan pada pelanggan bus efisiensi. Jurnal Administrasi Bisnis Vol 2, No 1.

[18]. Meyer, C. and Schwager, A. (2007). Understanding customer experience. Harvard Business Review. Vol 85 No2, pp.116-26

[19]. Pew Research Centre Forum on Religious and Public Life. (2014). The Future of the Global Moslem population. Washington DC USA : Pew Research.

[20]. Reichheld, F.F. (1994). Loyalty and the renaissance of marketing. Marketing Management,Vol. 2 No. 4, pp. 10-20.

[21]. Rinschede, G. (1992). Forms of religious tourism. Annals of Tourism Research, 19, 5167.

[22]. Reuters, T., Standard, D. (2016). State of the Global Islamic Economy Report 2016/17. Dubai: Dubai the Capital of Islamic Economy.

[23]. Robinette, Scott \& Claire brand. (1991). Emoticon Marketing, United States:Mc Grow Hill

[24]. Schmitt, B. H. (1999). Experiential Marketing : How to Get Customers to Sense, Feel, Think, Act, and Relate to Your Company and Brands. New York: FreePress.

[25]. Shaw, Colin and Ivens, John. (2007). Building Great Customer Experiences.

[26]. Suherlan, Ade. (2015). Persepsi Masyarakat Jakarta Terhadap Islamic Tourism. The Journal of Tauhidinomics Vol. 1 No. 1 (2015): 61-72.

[27]. Sumardi \& Soliha E. (2015). The Effect of Bank Image and Trust on Loyality Mediated by Customer Satisfaction. Jurnal Dinamika Manajemen 6 (2)

[28]. Tourism Review. (2013, April 01). Tourism-Review. Retrieved from http://www.tourism-review.com/indonesia-launches-sharia tourism-projects news3638.

[29]. UNWTO. (2014). Annual Report 2014. Madrid : Spain. 
[30]. Usman, H., \& Sobari, N. (2013). Aplikasi Teknik Multivariate Untuk Riset Pemasaran. Jakarta : Rajawali Press.

[31]. Wijanto, Setyo Hari. (2007), Structural Equation Modeling. Penerbit Graha Ilmu : Yogyakarta

[32]. Wuryasti, F. (2013, October 10). Wisata halal, konsep baru kegiatan wisata di Indonesia. Retrieved from

[33]. http://travel.detik.com/read/2013/10/30/152010/2399509/ 1382/.

[34]. You Ming, Chou. (2010). Study On The Impacts Of Experiential Marketıng And Customers' Satisfaction Based On Relationshıp Qualıty. The International Journal of Organizational Innovation Vol 3 Num 1 Summer 2010 pp.189-209.

[35]. Zoel. (2011, April 2009). Customer Value. Retrieved from http://www.marketing.co.id/customer-value/ 